\title{
Davalintide Acetate
}

National Cancer Institute

\section{Source}

National Cancer Institute. Davalintide Acetate. NCI Thesaurus. Code C83651.

The acetate salt form of davalintde, a second-generation, 32-amino acid peptide analogue of human amylin with antihyperglycemic activity. By mimicking amylin, davalintide, which has a half-life similar to amylin, slows gastric emptying, inhibits digestive secretions (gastric acid, pancreatic enzymes, and bile), reduces glucagon secretion, and increases satiety. These actions results in a decrease in blood glucose levels. Furthermore, davalintide exhibits high affinity binding to amylin, calcitonin and calcitonin-related peptide receptors. Compared to amylin, davalintide shows a prolonged duration of action due to its slowed receptor dissociation. 